\title{
The Relationship between Game Addiction and Personality Traits ${ }^{1}$
}

\author{
Ertan Basha
}

AAB College, Faculty of Psychology

\begin{abstract}
This study aims to examine the relationship between children's game addiction and personality traits and whether children's game addiction levels differ significantly according to age, class level, and gender. This research was conducted on teenagers in the British high school of Kosovo, which is located in Pristina. The sample was composed of 239 teenagers studying at high school in Kosovo in the academic year of 2016-2017. The sample of the study consisted of 239 teenagers between the ages of 12-17. $130(54.4 \%)$ of the participants were female and 109 (45.6\%) were male. In the research, first of all, the normality of the data was tested, and since it was determined that the data were normally distributed, analyzes were carried out using parametric tests. As a result of the analysis, game addiction of children was found to be negatively correlated with a personality tra, and positively correlated with a neurotic personality trait. No relationship was found between game addiction and personality traits such as extraversion. There was no significant mean difference between game addiction and age, gender, and grade level. As a result, there is a relationship between game addiction and tendermindedness personality traits and neuroticism. The fact that game addiction is not related to age and grade level may be due to the fact that the sample has similar developmental characteristics.
\end{abstract}

Keywords: Adolescence, game addiction, personality traits, addiction.

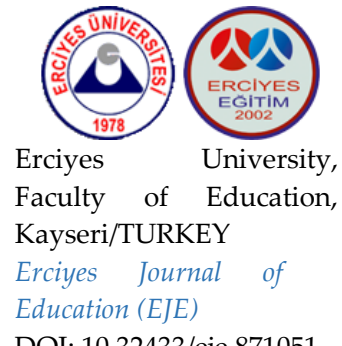

DOI: $10.32433 /$ eje. 871051

Basha, E. (2021). The relationship between game addiction and personality traits. Erciyes Journal of Education, 5(2), 149160. https://doi.org/10.32433/eje.871051

\footnotetext{
${ }^{1}$ This study is a developed version of an an academic paper presented in "International Symposium of Education and Values". Date: 10-13 September İstanbul / Turkey.

1. Assist Prof. Dr., Faculty of Psychology, AAB College, Pristine, Kosovo, ertan.basha@aab-edu.net, https://orcid.org/0000-0002-5231-7806
} 


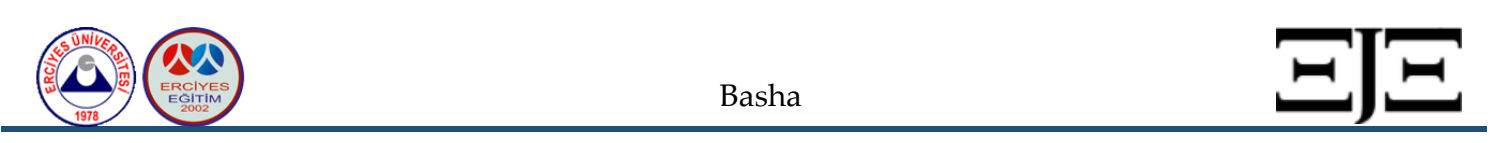

Erciyes Journal of Education 2021, Vol 5, No 2, 149-160

\section{INTRODUCTION}

Research on game addiction, which is considered within the scope of behavioral addictions, is increasing daily. Although game addiction affects people from all strata, it mostly affects children and teenagers (Taş \& Sevinç, 2019). Thus, it is important to investigate game addiction and related variables in children and teenagers. After the use of the internet in the world became widespread and problems related to internet use emerged, two terms were defined. The first one is pathological computer use, and the second one is internet addiction. Liu \& Potenza, (2007), computer game addiction, pathological internet use, problematic internet use, internet addiction, game addiction, internet gaming disorder, game playing disorder. When these terms are analyzed, addiction or disorder starts from a technological device such as a computer, and then it was named with applications on the internet such as games (Aral \& Doğan Keskin, 2018). According to the Diagnostic and statistical manual of mental disorders (DSM-V), addiction is the repetitive use of alcohol or drugs. A person which is addicted to drugs or alcohol cannot prevent the involuntary use of substances. Internet addiction and game addiction are considered as different terms (Kuss \& Griffiths, 2012). In studies on game addiction in adolescents, games would cause negative results in adolescent lives. In terms of the cognitive domain, adolescents have difficulties such as low cognitive flexibility, difficulty in responding (Zhou et. al., 2012), giving repetitive answers, and falling into repetitive mistakes (Han et. al., 2012). In another study, they found that it causes problems with attention deficit hyperactivity disorder, major depression disorder, anxiety, and impulsivity in psychopathological dimensions (Aboujaoude et. al., 2006). To be able to diagnose addiction, there must be DSM-V diagnostic criteria. These criteria are mainly; developing tolerance, withdrawal symptoms, having thoughts about quitting the substance but still failing, using high doses and long-term substances, limiting the life of the substance user in social, cultural, and personal areas. It is the continuation of substance use by a person despite causing physical, psychological, and social problems in his life. The diagnosis of addiction is made when three of these criteria are found (APA, 2013). Such intensive usage brings certain problems along. Long-term and uncontrolled usage of the internet may lead to physical, psychosocial, cognitive, and developmental problems (Çetin \& Ceyhan, 2014). Other internet addiction-related problems include insomnia, nutritional problems (not eating for a long time), and deterioration in school and working life (Cao \& Su, 2006). As maladaptive usage of the internet may cause psychological problems, there is a drastic increase in the number of studies on the effects of the internet on mental health (Beranuy, et. al, 2009).

Nowadays, technology games hantered children's life (Horzum, 2011). Research about digital technology shows us that playing computer games controlled and at an appropriate time can have an impact on children's lives such as learning new information and improving themselves (Vlachopoulos \& Makri, 2017). However, some features and emotions of digital games are considered as factors that support the development of addiction in the player. These features and emotions cause players to spend a long time and become addicted to games. (Irmak \& Erdoğan, 2015). Working adults can think of playing computer games during short breaks at their workplaces, adolescents, and children in school breaks, or a computer game that they will play at the end of the lesson (Basha \& Topal, 2020). Excessive use of digital games by children and teenagers can have negative effects on psychological, physiological, and social relationships (Juliane et. al., 2019). It can cause negative consequences especially on their personalities, and the tendency to violence can be observed more in children who play violent games at an early age (Juliane et. al., 2019). Distinctive personality refers to the tendency and behavior sets that make 
the individual unique. Although individuals display similar behaviors from time to time, they have certain characteristics that make them unique, and this makes them different from other individuals. The basis of this difference is the intensity and frequency of behavioral tendencies exhibited by individuals (David \& Huczynski, 1997). As a result, individuals who differ in physical, mental, and emotional aspects interpret events and facts differently. These differences form the basis of personality (Durna, 2005). However, as a common expression of all approaches, personality can be defined as characteristic (consistent with each other) behavioral patterns and thought strains that determine an individual's adaptation to the environment (Atkinson et. al., 1995).

The Five-Factor Model is a model made by Costa and McCrae (1992), which refers to the five factors of personality traits. The theory identifies five factors: 1) Neuroticism (for example, being nervous and anxious), 2) Extraversion (for example, being outgoing and extroverted), 3) Being open to experience (being creative and intellectually oriented), 4) Agreeableness (for example, being friendly and compassionate) and 5) Conscientiousness (for example, being organized and efficient) (Wiggins, 1 five-factoring factor model suggests that an individual's personality can be defined by examining five independent factors. This field shows us that there are different variables related to game addiction and personality traits. In a study conducted by Taş and Ayas (2015), internet addiction levels differed according to personality traits. The level of internet addiction had a low level of negative correlation with the personality trait of extraversion, a low level of positive correlation with a self-control personality trait, and a low level of negative correlation with the personality trait of openness to experience. In another study, aggression and narcissistic personality traits were positively associated with online game addiction, while selfcontrol was negatively correlated with online game addiction (Kim et al. ,2008). In a sample of 405 players from another digital game, World of Warcraft, they tested a multiple mediation model in which the relationship between the vulnerable / grandiose narcissism and the problematic game is mediated by emotion dysregulation and escapism, and their results showed that it fits very well with the model of vulnerable narcissism (but not grandiose) (Di Blasi et. al., 2020). In the study conducted by Wang et. al., (2015), personality traits of adolescents accompanying internet addiction were analyzed. In the study, high neuroticism and low self-discipline significantly accompanied internet addiction. When personality traits were evaluated in terms of internet applications, low self-discipline, and low openness to experience significantly accompanied online game addiction, while neuroticism and extroversion accompanied social network addiction at a significant level. Vollmer et. al., (2014) determined in their study that extroverts and tender-mindedness were less game addicted. In a study conducted by Kuss et. al.,(2013), 3.2\% of the students were internet addicts. Neuroticism, one of the personality traits, was the strongest predictor of internet addiction. The significant relation was seen in tendermindedness which was the second personality trait. This score was found to be significantly lower in internet addicts than non-addicts. The personality trait of openness to experience was significantly higher in internet addicts than non-addicts. Two main predictors of internet addiction were found in the study. It has been determined that while openness to experience predicts online gaming, neuroticism significantly predicts online shopping (Wang et. al., 2015). To examine the relationships between personality traits, a sample of 920 participants from four secondary schools was taken from the Big Five model, and the results showed a significant difference in personality traits for different addictive behaviors, specifically, higher neuroticism and less conscientiousness, internet addiction in general; less conscientiousness and low openness were significantly associated with game addiction; neuroticism and extraversion were significantly associated with social network addiction. Laier et. al., (2018) assume that 
incompatible personality traits are important factors for the development of internet game disorder, along with positive expectations and avoidance expectations about the game. However, they argue that positive expectations and avoidance expectations play a different role in mediating between personality traits and symptoms.

This study aims to examine the relationship between game addiction and personality traits in children and teenagers. Lately, as technology improves and as we find tools to use them everywhere, starting from smartphones which include a lot of gaming, children spend more time playing with them rather than playing outside. On the other hand, individuals working in the field of mental health are doing more studies on these issues because internet games are free and the game addiction of children increases. When studies on game addiction and game addiction in adolescents were examined, this kind of research was not found in Kosovo, and this is the reason why this topic is researched.

\section{METHOD}

\section{Research Model}

This study examining the relationship between gaming addiction and personality traits among children used the survey model. As the relationship between two or more variables is examined without intervention with the variables, this is a correlational research study (Büyüköztürk, Kılıç Çakmak, Akgün, Karadeniz \& Demirel, 2010).

\section{Participants}

This research was conducted on teenagers in the British high school of Kosovo, which is located in Pristina. The sample was composed of 239 teenagers studying at high school in Kosovo in the academic year of 2016-2017. The sample of the study consisted of 239 teenagers between the ages of $12-17.130(54.4 \%)$ of the participants were female and $109(45.6 \%)$ were male.

\section{Data Collection}

The data was collected by interviewing the students and applying the scale forms to them in the high school selected according to the accessibility criteria. First, we got the permission from the director of the British high school of Kosovo, then the students were informed about the importance of the study and asked to answer the items honestly in the interview. Moreover, they were told that they did not get to give credentials. Out of 300 participants, 61 did not undergo the analysis because the surveys were not complete. Eventually, the data analysis was done with 239 participants.

\section{Data Collection Tools}

\section{Personality Traits Scale}

Before using the scale, we contacted the author through e-mail and we got the premission for using the Personality Traits Scale by Horzum et. al., (2017). The ten-item personality scale developed by Rammstedt and John (2007), which measures five basic personality traits, was used, and it was adapted to Turkish culture and language by Horzum et. al., (2017). The findings obtained from the linguistic equivalence study of the scale showed that the correlation between Turkish and English original forms was quite high. The results of the exploratory and 
confirmatory factor analysis of the scale, the results regarding the construct validity, and the findings obtained regarding the reliability of the scale showed that the scale was a reliable measurement tool in Turkish culture. Although the internal consistency rate for the subdimensions of the scale varied between .81 and. 90, it was determined that the composite value varied between .73 and .85 . The fact that all of the internal consistency and composite reliability value are higher than .70 shows that the reliability values of the scale are high, which means it produces consistent data.

\section{Game Addiction Scale}

Before using the scale, we contacted the authors of the Game Addiction Scale through the mail and we got permission to use it. In the study, the game addiction of the students was measured using the "Game Addiction Scale" developed by Lemmens et. al., (2009). As a result, reliability analysis was made with first and second-level factor analysis. First level factor analysis fit index results $\left(x^{2}(165, N=265)=2.71 .01, p<0.000, R M S E A=0.049, S-R M R=0.046, G F I=0.91, A G F I=0.88\right.$, $C F I=0.99, N N F I=0.98, I F I=0.99)$ and second-order factor analysis results $\left(x^{2}(179, N=265)=331.68, p<\right.$ 0.000, RMSEA=0.057, S-RMR=0.051, GFI=0.89, AGFI=0.86, CFI=0.98, NNFI=0.98, IFI=0.98) scale shows that gives good results. The Cronbach Alfa has value of 0.92 (Ilgaz, 2015). Scale is a fivepoint Likert scale grading that was used for opinions about the game addiction test. This rating was formed as "Always (5), Most of the time (4), Frequently (3), Occasional (2), and Rarely (1)".

\section{Analysis of Data}

The data were collected by interviewing the students and applying the scale forms to them in the high school selected according to the accessibility criteria. The students were informed about the importance of the study and asked to answer the items sincerely in the interview. They were also told that they did not have to provide credentials. Data were collected from 239 participants in total. 61 of the data were not subjected to the analysis because they were incomplete. The analysis was performed with 239 participants. For performing a multiple regression analysis, data of dependent variables need to have a normal distribution, there cannot be any auto-correlation, and there cannot be any multiple relation problem between independent variables (Kalayc1, 2014). The analyses were carried out in SPSS 22 software package.

\section{FINDINGS}

This study aims to examine the relationship between children's game addiction and personality traits, and whether children's game addiction levels differ significantly according to age, class level, and gender. First of all, the normality of the data was tested via the Kolmogorov-Smirnov coefficient. Kolmogorov-Smirnov coefficient calculated for the Game Addiction Scale is 0.355. Since Kolmogorov-Smirnov coefficients are greater than $p>.05$, it is assumed that the data show normal distribution (Can, 2014). There are independent samples t-test, correlation analysis results and findings related to the prediction of game addiction according to personality traits.

Table 1. Table of game addiction changes by gender $(N=239)$

\begin{tabular}{|c|c|c|c|c|c|c|}
\hline Game Addiction & $\mathbf{N}$ & $\overline{\mathbf{x}}$ & SD & $\mathbf{t}$ & Df & $\mathbf{P}$ \\
\hline Male & 109 & 42.9059 & 13.0806 & \multirow{2}{*}{-1.029} & \multirow[b]{2}{*}{237} & \multirow[b]{2}{*}{.304} \\
\hline Female & 130 & 44.7045 & 13.7625 & & & \\
\hline
\end{tabular}


The mean scores of children's change levels of game addiction by gender are presented in Table 1. The result of the independent samples t-test performed to determine whether the mean difference in the mean score of game addiction levels of males and females is significant, it was found $(p<0.05)$ level the difference was not significant.

Tablo 2. The relationship between game addiction, grade, and age

\begin{tabular}{lccc}
\hline Variables & Game Addiction & Grade & Age \\
\hline \multirow{2}{*}{ Game Addiction } & 1 & .052 & .007 \\
& & .423 & .917 \\
Grade & 1 & $.944^{* *}$ \\
Age & & .148 \\
\hline
\end{tabular}

To test the relationship between variables person's correlation coefficient was used due to the dataset have normality distribution. When Table 2 was examined, a statistically significant relationship was not found between the game addiction levels of children and grade $(r=0.423, p>$ 0.05). Similarly, no statistically significant relationship was found between children's game addiction levels and age $(r=.917 \mathrm{p}>0.05)$.

Table 3. Relations Between Game Addiction and Personality Traits Sub-Dimensions of Adolescents ( $N=$ 239)

\begin{tabular}{|c|c|c|c|c|c|c|}
\hline & $\begin{array}{l}\text { Game } \\
\text { Addiction }\end{array}$ & Extroversion & $\begin{array}{l}\text { Tender- } \\
\text { Mindedness }\end{array}$ & $\begin{array}{l}\text { Self- } \\
\text { Control }\end{array}$ & Neuroticism & $\begin{array}{l}\text { Openness } \\
\text { to } \\
\text { experience }\end{array}$ \\
\hline $\begin{array}{l}\text { Game } \\
\text { Addiction }\end{array}$ & $\begin{array}{l}1 \\
-\end{array}$ & $\begin{array}{l}-.020 \\
.760\end{array}$ & $\begin{array}{l}-.155^{*} \\
.016\end{array}$ & $\begin{array}{l}-.041 \\
.526\end{array}$ & $\begin{array}{l}.248^{* *} \\
.000\end{array}$ & $\begin{array}{l}.051 \\
.437\end{array}$ \\
\hline Extroversion & - & 1 & $\begin{array}{l}.274^{* *} \\
.000\end{array}$ & $.305^{* *}$ & $\begin{array}{l}-.084 \\
.195\end{array}$ & $\begin{array}{l}.181^{* *} \\
.005\end{array}$ \\
\hline $\begin{array}{l}\text { Tender } \\
\text { Mindedness }\end{array}$ & - & - & 1 & $\begin{array}{l}.393^{* *} \\
.000\end{array}$ & $\begin{array}{l}-.023 \\
.718\end{array}$ & $\begin{array}{l}.260^{* *} \\
.000\end{array}$ \\
\hline Self- Control & - & - & - & 1 & -.030 & $\begin{array}{l}.348^{* *} \\
.000\end{array}$ \\
\hline Neuroticism & - & - & - & - & 1 & $\begin{array}{l}.051 \\
.435\end{array}$ \\
\hline $\begin{array}{l}\text { Openness to } \\
\text { experience }\end{array}$ & - & - & - & - & - & 1 \\
\hline
\end{tabular}

In Table 3, play addiction personality traits in children were negatively associated with tender mindedness personality, $\left(\mathrm{r}=-.155^{* *}, \mathrm{p}>0.05\right)$ and positively correlated with neurotic personality traits. $(\mathrm{r}=.248, \mathrm{p}>0.05)$. No relationship was found between game addiction personality traits such as extraversion $(r=-.02, p>0.05)$, self-control $(r=-.041, p>0.05)$ and openness to experience. $(\mathrm{r}=.051, \mathrm{p}>0.05)$. 


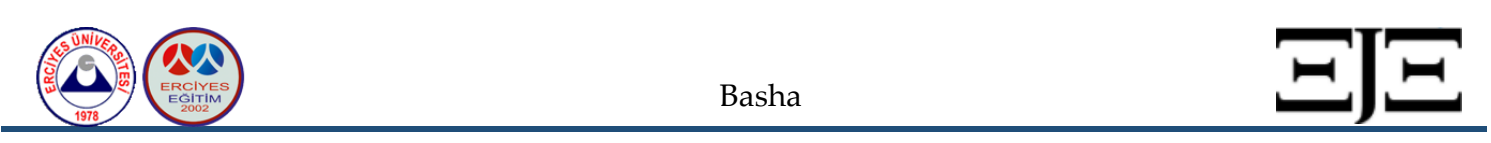

Erciyes Journal of Education 2021, Vol 5, No 2, 149-160

\section{DISCUSSION \& CONCLUSION}

This study aims to investigate the possible relationship between personality traits and video game addiction, especially the stages of adolescence, when most things change. On the other hand, individuals working in the field of mental health are doing more studies on these issues because internet games are free and the game addiction of children increases. When the children's game addiction was examined by gender, the mean difference was not significant. When all the findings are evaluated, the level of computer game addiction varies according to gender in general. This finding is consistent with the results by Hsu, Wen et al. (2009), İnal and Çağıltay (2005), Çakır et al. (2011), Keser and Esgi (2012), and Turner et al. (2012). In the study conducted by Li and Wang (2013), game addiction was found more in boys than in girls. In most of the studies on game addiction, boys are more addicted. The reason for this may be that boys have the opportunity to spend more time on the internet. Internet addiction scores of the students, which is a second variable of the study, were found to be significantly different according to the grade they were educated. This finding was also found by Günüç (2009), Kubey et al. (2001), Çakır et al. 2011), Doğan (2013), and Yilmaz et al. (2014). On the other side, according to the studies conducted by Çakır et al. (2011), was found no significant relationship between grade level and internet addiction. As a second variable of the study, the game addiction did not differ significantly according to the grade level of the students. This finding is consistent with the studies by Çakır et al. (2011), Turner et al. (2012), and Keser and Esgi (2012). According to the studies conducted by Horzum (2011) and Şahin and Tuğrul (2012), there is a significant relationship between game addiction and grade level.

According to some research results, game addiction levels of male students are higher than female students. Studies on game addiction have indicated that game addiction is higher in boys than in girls (Horzum, 2011). Examining the game addiction levels of primary school students, the addiction levels of boys were higher than girls. It is consistent with the findings of research on game translation (Griffiths \& Hunt, 1995; Griffiths \& Hunt, 1998; Kubey et al., 2001; Bonannoa \& Kommers, 2005; Fisher, 1994; Funk, 1993). Most of the studies on game addiction show that men are more addicted. These results are not consistent with our research results. During the stages of adolescence, caused both boys and girls were to spend more time at home, but there was no significant relationship between boys and girls in the study. We can say that at this time, both boys and girls played games to distance themselves from routine life. In addition, the fact that it does not differ significantly according to gender may be because both sexes have the same access to technological devices.

When another finding of the study was examined, play addiction personality traits were negatively related to the personality trait of tender-mindedness and positively related to neurotic personality traits. No relationship was found between play addiction and extraversion, selfcontrol, and personality traits of openness to experience. No relationship was found between game addiction and grief. There are different variables related to game addiction and personality traits. In a study conducted by Taş and Ayas, (2015), internet addiction levels differ according to personality traits. The level of internet addiction has a low level of negative correlation with the personality trait of extraversion, a low level of positive correlation with a self-control personality trait, and a low level of negative correlation with the personality trait of openness to experience. In another study, Kim et al. (2008) found that aggression and narcissistic personality traits were positively associated with online game addiction, while self-control was negatively correlated with online game addiction. In a sample of 405 World of Warcraft online game players, they 
tasted a multiple mediation model in which the relationship between vulnerable / grandiose narcissism and problematic gaming was mediated by emotion dysregulation and escapism. Results showed that the model for vulnerable (but not grandiose) narcissism fitted the data very well (Di Blasi et al., 2020). In the study conducted by Wang et al. (2015), personality traits of adolescents accompanying internet addiction were analyzed. High neuroticism and low selfdiscipline significantly accompanied internet addiction. When personality traits were evaluated in terms of internet applications, low self-discipline, and low openness to experience significantly accompanied online game addiction, while neuroticism and extroversion accompanied social network addiction at a significant level. Vollmer et al. (2014) determined in their study that extroverts and tender-mindedness people were less game addicted. In a study conducted by Kuss et al. (2013), 3.2\% of the students were internet addicts. Neuroticism, one of the personality traits, was the strongest predictor of internet addiction. The second personality trait with a significant relationship in the study was tender-mindedness. This score was found to be significantly lower in internet addicts than non-addicts. The personality trait of openness to experience was significantly higher in internet addicts than non-addicts. Two main predictors of internet addiction were found in the study. While openness to experience predicts online gaming, neuroticism significantly predicts online shopping (Wang et al., 2015). To examine the relationships between personality traits, 920 participants from four secondary schools were taken as a sample of the Big Five Model and the results showed a significant mean difference in personality traits for different addictive behaviors. Specifically, higher neuroticism and less conscientiousness, internet addiction in general; less conscientiousness and low openness were significantly associated with game addiction; neuroticism and extraversion are significantly associated with social network addiction. Laier et al. (2018) assume that maladaptive personality traits in combination with game-related positive expectancies and avoidance expectancies are important factors for the development of Internet Gaming Disorder (IGT), but that positive expectancies and avoidance expectancies play a differential roles between personality characteristics and symptoms of IGD. They argued that it played a different role (Jeong et. al., 2015). In conclusion, neuroticism increases game addiction and extroversion does not affect addiction. Another result of the same study is that as loneliness and game addiction increase, depression addiction increases negatively.

As a result, there is a relationship between game addiction and personality traits, tendermindedness, and neuroticism in adolescents. No relationship was found between game addiction and age. In addition, game addiction did not differ significantly according to gender and grade level. The fact that game addiction is not related to age and grade level may be due to the similar developmental characteristics of the samples. On the other hand, looking at the results, we can say that some psychological features such as aggression, self-control, and narcissistic personality traits can cause some individuals to addicted to online games. The results obtained in this study are to deepen the understanding of the population "at -risk" for game addiction in adolescents and to contribute to the development of a prevention program for game addicted adolescents. However, despite its contribution to the field, it has some limitations. The sample consists of a limited number of adolescents in the province of Prishtina. The studies to be done need to be supported with different samples. Advanced statistics can be preferred for the detection of latent variables and mediator variables that may be effective in game addiction. In addition, to understand the reasons why adolescents play games and the factors that may be efficient, it will be useful to support qualitative data to gather in-depth information.

Conflict of Interest Statement: The author has not declared any conflict of interest. 


\section{REFERENCES}

Aboujaoude, E., Koran, L. M., Gamel, N., Large, M. D., and Serpe, R. T. (2006). Potential markers for problematic internet use: a telephone survey of 2,513 adults. CNS Spectrums, 11(10), 750-755.

American Psychiatric Association (APA) (2013). Diagnostic and statistical manual of mental disorders (DSM-5®). American Psychiatric Pub.

Aral, N. ve Doğan Keskin, A. (2018). Ebeveyn bakış açısıyla 0-6 yaş döneminde teknolojik alet kullanımının incelenmesi. Addicta: The Turkish Journal on Addictions, 5(2), 317-348.

Atkinson, R. L., Atkinson, R. C., and Hilgard, E. R. (1995). Psikolojiye giriş (K. Atakay, M. Atakay ve A. Yavuz, Çev.). Sosyal Yayınlar.

Balkaya Çetin, A. and Ceyhan, A. A. (2014). Ergenlerin internette kimlik denemeleri ve problemli internet kullanım davranışları. Addicta: The Turkish Journal on Addiction, 1(2), 5-46.

Basha, E., and Topal, M. (2020). Bilgisayar oyun bağımlılığı ölçeğinin arnavutça'ya uyarlanması çalışması. Online Journal of Technology Addiction and Cyberbullying, 7(2), 52-69.

Beranuy, M., Oberst, U., Carbonell, X., and Chamarro. (2009). Problematic Internet and mobile phone use and clinical symptoms in college students: The role of emotional intelligence. Computers in Human Behavior, 25, 1182-1187.

Bonannoa, P. and Kommers, P. A. M. (2005). Gender differences and styles in the use of digital games. Educational Psychology, 25(1), 13-14.

Büyüköztürk, Ş., Kılıç Çakmak, E., Akgün, Ö. E., Karadeniz, Ş., and Demirel, F. (2010). Bilimsel araştırma yöntemleri. Pegem Akademi.

Can, A. (2014). SPSS ile bilimsel araştırma sürecinde nicel veri analizi (3rd ed.) Pegem Akademi.

Cao, F. and $\mathrm{Su}$, L. (2006). Internet addiction among Chinese adolescents: Prevalence and psychological features. Child: Care, Health and Development, 33(3), 275-281.

Costa, P. T. and McCrae, R. R. (1992). Four ways five factors are basic. Personality and Individual Differences, 13, 653-665.

Çakır, Ö., Ayas, T. and Horzum, M. B. (2011). An investigation of university students' internet and game addiction with respect to several variables. Ankara University Journal of Faculty of Educational Sciences, 44(2), 95-117.

David, B., and Huczynski, A. (1997). Organizational behavior. An introductory text. Prentice-Hall International. 
Di Blasi, M., Giardina, A., Coco, G. L., Giordano, C., Billieux, J., and Schimmenti, A. (2020). A compensatory model to understand dysfunctional personality traits in problematic gaming: The role of vulnerable narcissism. Personality and Individual Differences, 160, 16.

Doğan, A. (2013). İnternet bağımlılığı yaygınlığı (Unpublished master's thesis). Dokuz Eylül University.

Durna, U. (2005). A ve B Tipi kişilik yapılarını ve bu kişilik yapılarını etkileyen faktörlerle ilgili bir araştırma. İktisadi ve İdari Bilimler Dergisi, 19(1), 276- 290.

Fisher, S. (1994). Identifying video game addiction in children and adolescents. Addictive Behaviors, 19, 545-553.

Funk, J. B. (1993). Reevaluating the impact of video games. Clinical Pediatrics, 32(2), 86-90.

Günüç, S. (2009). İnternet Bağımlılık Ölçeğinin geliştirilmesi ve bazı demografik değişkenler ile İnternet bağımlılığı arasındaki ilişkilerin incelenmesi. (Yüksek Lisans). Yüzüncü Yıl Üniversitesi Sosyal Bilimler Enstitüsü.

Griffiths, M. D. and Hunt, N. (1995). Computer game playing in adolescence: Prevalence and demographic indicators. Journal of Community \& Applied Social Psychology, 5(3), 189-193.

Griffiths, M. D. and Hunt, N. (1998). Dependence on computer games by adolescents. Psychological Reports, 82(2), 475-480.

Han, D. H., Lyoo, I. K., and Renshaw, P. F. (2012). Differential regional gray matter volumes in patients with on-line game addiction and professional gamers. Journal of Psychiatric Research, 46(4), 507-515.

Horzum, M. B. (2011). İlköğretim öğrencilerinin bilgisayar oyunu bağımlılık düzeylerinin çeşitli değişkenlere göre incelenmesi. Ĕ̆itim ve Bilim, 36(159), 56-68.

Horzum, M. B., Tuncay, A., and Padır, M. A. (2017). Adaptation of big five personality traits scale to Turkish culture. Sakarya University Journal of Education, 7(2), 398-408.

Hsu, S. H., Wen, M. H., and Wu, M. C. (2009). Exploring user experiences as predictors of MMORPG addiction. Computers and Education, 53, 990-998.

Ilgaz, H. (2015). Ergenler için oyun bağımlılı̆̆ı ölçeğinin Türkçeye uyarlama çalışması. İlköğretim Online, 14(3), 874-884.

Irmak, Y. A., and Erdoğan, S. (2016). Ergen ve genç erişkinlerde dijital oyun bağımlılı̆̆ı: Güncel bir bakış. Türk Psikiyatri Dergisi, 27(2), 128-137.

İnal, Y., and Çagıltay, K. (2005). İlköğretim Öğrencilerinin Bilgisayar Oyunu Oynama Alışkanlıkları ve Oyun Tercihlerini Etkileyen Faktörler. Ankara Özel Tevfik Fikret 
Okulları, Eğitimde Yeni Yönelimler II. Eğitimde Oyun Sempozyumu: 14 Mayıs 2015 Ankara.

Jeong, E. J., Lee, H. R., and Yoo, J. H. (2015). Addictive use due to personality: Focused on Big Five personality traits and game addiction. International Journal of Social, Behavioral, Educational, Economic, Business, and Industrial Engineering, 9(6), 1995-1999.

Juliane, M., Braun, B., Müller, K.W., and Egloff, B. (2019). The Association between video gaming and psychological functioning. Frontiers in Psychology, 10, 1731.

Kalaycı, Ş. (2014). SPSS uygulamalı çok değişkenli istatistik teknikleri. Asil Yayınları.

Keser, H., and Esgi, N. (2012). An Analysis of self-perceptions of elementary school students in terms of computer game addiction. Procedia - Social and Behavioral Sciences, 46, 247-251.

Kim, E. J., Namkoong, K., Ku, T., and Kim, S. J. (2008). The relationship between online game addiction and aggression, self-control, and narcissistic personality traits. European Psychiatry, 23(3), 212-218.

Kubey, R. W., Lavin, M. J., and Barrows, J.R. (2001). Internet use and collegiate academic performance decrements: Early findings. Journal of Communication, 51(2), 366-382.

Kuss D. J. and Griffiths M. D. (2012). Online gaming addiction in children and adolescents: A review of empirical research. Journal of Behavioral Addictions, 1(1), 3-22.

Kuss, D. J., Griffiths, M. D., and Binder, J. F. (2013). Internet addiction in students: Prevalence and risk factors. Computers in Human Behavior, 29(3), 959-966.

Li, H. and Wang S. (2013). The role of cognitive distortion in online game addiction among Chinese adolescents. Children and Youth Services Review, 35, 1468-1475.

Laier, C., Wegmann, E., and Brand, M. (2018). Personality and cognition in gamers: Avoidance expectancies mediate the relationship between maladaptive personality traits and symptoms of Internet-gaming disorder. Frontiers in Psychiatry, 9, 1-8.

Lemmens J. S., Valkenburg, P. M., and Peter J. (2009). Development and validation of a game addiction scale for adolescents. Media Psychology, 12, 77-95.

Liu, T., and Potenza, M. N. (2007) Problematic internet use: clinical implications. CNS Spectrums. 12(6), 453-466.

Rammstedt, B., and John, O. P. (2007). Measuring personality in one minute or less: A 10-item short version of the Big Five Inventory in English and German. Journal of Research in Personality, 41(1), 203-212.

Şahin, C., and Tuğrul, V. M. (2012). Ilköğretim öğrencilerinin bilgisayar oyunu bağımlılık düzeylerinin incelenmesi. Zeitschrift für die Welt der Türken / Journal of World of Turks, 4(3), 115-130. 
Taş, İ., and Sevinç, H. (2019). Çocuklarda aleksitimi, bilgisayar oyun bağımlılığı ve empatik eğilim arasındaki ilişki: bir yapısal eşitlik modellemesi. AYNA Klinik Psikoloji Dergisi, 6(3), 271-288.

Taş., İ., and Ayas, T. (2015). The relationship the level of internet addiction with personality traits of high school students. Journal of Human Sciences, 12(2), 150-162.

Turner, N. E., Paglia-Boak, A., Ballon, B., Cheung, J. T. W., Adlafi E. M., Henderson, J., Chan, V., Rehm, J., Hamilton, H., and Mann, R. E. (2012). Prevalence of problematic video gaming among Ontario adolescents. International Journal of Mental Health and Addiction, 10(6), 877-889.

Vlachopoulos, D., and Makri, A. (2017). The effect of games and simulations on higher education: a systematic literature review. International Journal of Educational Technology in Higher Education, 14(1), 1-33.

Vollmer, C., Randler, C., Horzum, M. B., and Ayas, T. (2014). Computer game addiction in adolescents and its relationship to chronotype and personality. Sage Open, 4(1), 1-9.

Wang, C. W., Ho, R. T., Chan, C. L., and Tse, S. (2015). Exploring personality characteristics of Chinese adolescents with internet-related addictive behaviors: Trait differences for gaming addiction and social networking addiction. Addictive Behaviors, 42, 32-35.

Wiggins, J. S. (1996). The five-factor model of personality: Theoretical perspectives. Guilford Publications.

Yılmaz, E., Şahin, Y. L., Haseski, H. İ., and Erol, O. (2014). Lise öğrencilerinin internet bağımlılık düzeylerinin çeşitli değişkenlere göre incelenmesi: Balıkesir ili örneği. Journal of Educational Sciences Research, 4(1), 133-144.

Zhou, Z., Yuan, G., and Yao, J. (2012). Cognitive biases toward internet game-related pictures and executive deficits in individuals with an Internet game addiction. PloS One, 7(11), 1-9. 